\title{
Statyba
}

\section{PROCEDURES OF CITY TRANSPORT SYSTEMS' PLANNING}

\section{P. Juškevičius}

To cite this article: P. Juškevičius (1995) PROCEDURES OF CITY TRANSPORT SYSTEMS'

PLANNING, Statyba, 1:4, 45-66, DOI: 10.1080/13921525.1995.10531533

To link to this article: https://doi.org/10.1080/13921525.1995.10531533

曲 Published online: 26 Jul 2012.

Submit your article to this journal ¿

山 Article views: 80

7 Citing articles: 1 View citing articles 
ISSN 1392-1525. STATYBA - BUILDING CONSTRUCTION - CTPOИTE ЛЬCTBO, 1995, Nr. 4(4)

\section{MIESTU SUSISIEKIMO SISTEMU PLANAVIMO PROCESO PROCEDŪROS}

\section{P.Juškevičius}

\section{1. İvadas}

Susisiekimo planavimo procedūros ir jų loginè seka yra požiūrio, planavimo principų ir sąlygu išvestinè. Be abejo,čia didelę reikšmę turi susisiekimo procesų pažinimo lygis, specialistų patirtis ir galimybès, planavimo tradicijos.

Anksčiau egzistavo privalomoji planavimo tvarka. Nežiūrint dalinių modifikacijų, iš esmès ji išliko ir dabar, nes mechaniškai perimti kitų šalių geresnę patirtị neįmanoma. Neišvengiamai tektų ją taikyti Lietuvos sąlygoms, ypač tuos momentus, kurie susiję su socialiniais, ekonominiais, teisiniais dalykais, informaciniu aprūpinimu, aplinkosauginiais reikalavimais ir t.t. .

Tradicinès susisiekimo planavimo procedūros yra tokios:

- planuojamos teritorijos padalinimas į vadinamuosius transportinius rajonus,

- susisiekimo procesų tyrimas ir kitos planavimui reikalingos informacijos rinkimas, kaupimas ir tvarkymas,

- susisiekimo procesų analizé, désningumų nustatymas ir matematinių modelių sudarymas,

- susisiekimo poreikių ir procesu prognozè,

- susisiekimo sistemos plétojimo tikslų nustatymas,

- susisiekimo sistemos variantinis planavimas,

- susisiekimo sistemos varianty funkcinis ir ekonominis įvertinimas bei geriausiojo atrinkimas.

Ši procedūru visuma supaprastintai atspindi tradicini planavimą, t.y. determinuotus sprendinius, kiekybinį sistemos plètojimą, pagrįstą iš esmès vien funkciniais ir ekonominiais kriterijais.

Šiuolaikinè susisiekimo sistemos samprata kokybiškai skiriasi nuo ankstesnés. Todèl ją turètų atitikti kitoks planavimo procesas, procedūros ir jų turinys. Svarbiausia: turi atsirasti daugkartinis grị̌tamasis ryšys, interacinès sprendinių gerinimo procedūros, strateginių ir taktinių tikslų ar uždavinių ryšys, sprendinių paieškų tęstinumas, ịvertinant socialinius, ekonominius pokyčius ir t.t.

Visas susisiekimo planavimo procesas skaidytinas į sąlygiškai atskiras dalis. 


\section{Identifikavimas}

Formaliai planuojamo objekto nustatymas nèra problema. Tačiau dalykine prasme problema egzistuoja, ir ji yra ịvairaus hierarchinio lygmens.

Miesto susisiekimo sistemos planavimo darbų užsakovas paprastai yra savivaldybé, kuri miesto viešojo susisiekimo marł̌rutų aptarnaujamą arba miesto administracinę teritoriją sutapatina su planuojama teritorija. Tai administracinis požiūris, ir jis ne visada gali garantuoti planavimo sèkmę, nes miesto ir jam gretimos teritorijos turi intensyvius abipusius gyventojų ryšius, krovinių apyvartą. Lietuvos miestai nèra teritoriniu požiūriu išsiplètojusios aglomeracijos, tačiau gretimi miestai ir gyvenvietès, kolektyviniai sodai (tai potencialūs gyvenamieji rajonai) kartu su pagrindiniu miestu sudaro vieną funkcionuojančią sistemą, kuriai turètų egzistuoti vieningos komunikacinès sistemos atitikmuo. Be to, miesto susisiekimo sistema yra aukštesnio lygmens susisiekimo sistemos posistemè. Tai savo ruožtu reikalauja abipusio susisiekimo sprendinių suderinimo. Todèl miesto susisiekimo sistemos planavimas visada turètų vykti gerokai didesnèje teritorijoje, kurią galima pavadinti miesto įtakos zona.

Iš anksčiau atliktų autoriaus tyrimų, įtakos zonos tiksliausiai gali būti nustatytos pagal miestų, miestelių ir kaimų ryšių vyravimą i i vieną ar kitą gyvenvietę. Absoliuti Lietuvos miestų dauguma ir dalis kitų gyvenviečių turi susiformavusias itakos zonas. Kiti miestai su savo ịtakos zonomis patenka ị "stipresnių" itaką. Todèl gali būti ịvairiai interpretuojamos planuojamosios teritorijos ribos [1].

Plètojant sią mintị, miesto ịtakos zona turètų būti ne vien formali planuojama teritorija. Naudinga jai ịkurti ir susisiekimo sistemą reguliuojančią instituciją kelių savivaldybių ar miestų, administracinių rajonų susitarimu. Tokių pavyzdžių yra Olandijoje, JAV. Kaip, pavyzdžiui, tvirtinama straipsnyje [2], Paryžiaus viešojo susisiekimo sistema yra Šiuolaikiškesnė, kokybiškesnè ir 2-3 kartus pigesnè negu Londone. Viena iš priežasčių - susisiekimo sistemos valdymo Londone padalinimas atskiriems jo rajonams (dalims) ir dèl to atsiradęs sistemos funkcionavimo ir plètros suderinamumo trükumas.

Analogiškos problemos egzistuoja ir žemesniame lygmenyje. Gatvès, sankryžos, atskiro miesto maršruto planavimas, parkavimo sistemos ir bet kurie kiti pakeitimai atsilieps ne vien konkretaus objekto funkcionavimui, bet ir gretimoms, daug didesnèms teritorijoms ar miesto posistemèms, o kai kada ir visos sistemos veiklai (1 pav.). Šio lygmens susisiekimo planavimo objektų kategoriškas išankstinis identifikavimas ne visada įmanomas ir ne visada reikalingas. Svarbiausia, kad formaliai lokalus susisiekimo uždavinys būtų sprendžiamas visos susisiekimo sistemos kontekste.

Toks požiūris būtų prielaida kokybiškiau planuoti susisiekimą.

Planuojamos teritorijos nustatymas - tai tik vienas indentifikavimo aspektas. Kitas aspektas pačios susisiekimo sistemos, jos elementų, tarpusavio ryšių, aplinkos (tarp jų ir urbanistinès), kurioje vyksta susisiekimo procesai, pasekmių ir kainos identifikavimas. 


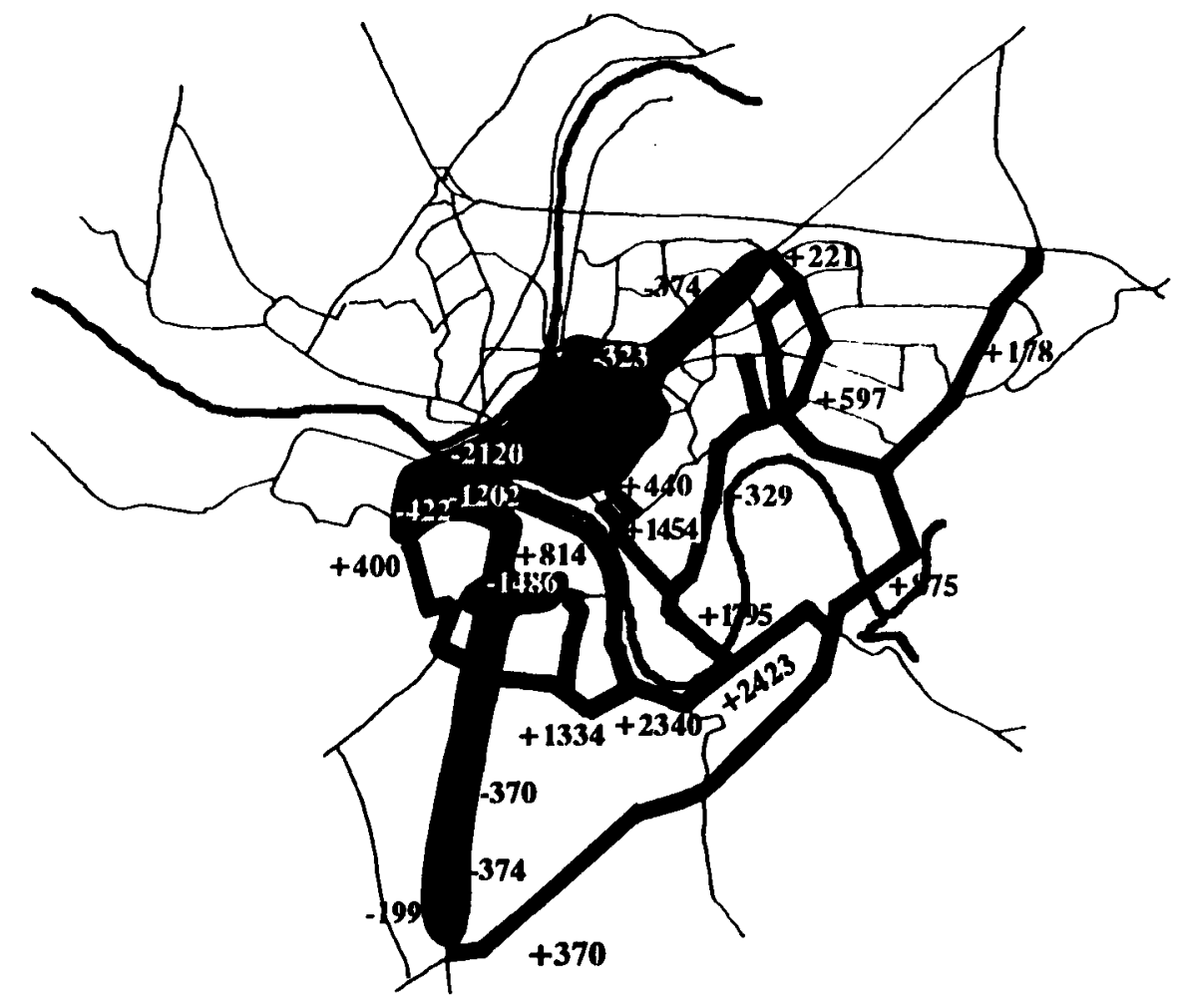

1 pav. Kauno Aleksoto tilto uždarymo pasekmès: lengvuju automobilių srauty̨ persiskirstymas gatvių tinkle. $1993 \mathrm{~m}$. srauty matematinio modeliavimo rezultatai.

-2120 ; ... srauto sumažèjimo gatvès pjüvyje dydis, aut./piko h., +2423 ;... srauto pricaugis, aut./piko $h$.

Bendru atveju identifikavimas galċtų būti tokių lygių:

a - micsto jitakos zonos mastu,

b - užstatytos teritorijos arba administraciniu miesto ribų rémuosc,

c - miesto dalių, rajony̨ ar kity max̌esnių teritorinių viencty mastu.

d - atskiro susisickimo sistemos vartotojo (gyventojų grupių ar įmonès) mastu.

Miestas ar jo jitakos zona, kaip ncdalomas fivinis, informacinis ar kitoks vicnctas, būtl aukštesnio (regiono, șalics) hicrarchinio lygmens susisickimo sistemos clementaরarba informacinc prasme - bendram, iliustraciniam micsto susisickimo sistemos apibūdinimui.

Lygmenys a, b ir c yra tradiciniai būdai, ir paprastai jic remiasi pradiniu planuojamos teritorijos padalinimu i transportinius rajonus, o po to agregavimu $i$ a, b lygi ar pagal porciki.

Dalinant planuojamają tcritorija rajonais, day̆niausiai buvo jvertinamas tik vienas kriterijus susisickimo pésčiomis crdvès dydis, kurio maksimumas galèty sickti $2,5-3 \mathrm{~km}^{2}$, o palankiausias dydis - 0,8-1,0 km². Šis principas būtų labai palankus susisickimo planavimo reikmèms, nes tcoriskai galętu ivykti ryškus kelionių pasidalinimas: rajono vidujc - pésčiomis, u» jo ribu transporto pricmonemis. Tačiat ši teorine schema ncalitinka realios siluacijos. (jyventoju ryšị, 
tarp jų ir pésčiomis, teritorinis pasiskirstymas sudaro nepertraukiamą lauką. Šiame lauke galima ieškoti tik sąlyginès skiriamosios ribos.

Teritorijos rajonavimas iš esmès yra miesto modelio sudarymas. Gatvių ir kity komunikaciju tinklas, transportinių rajony centrai su jiems suteikiama socialine, demografine, urbanistine bei kitokia informacija ir yra miesto modelis pagrindinèms susisiekimo planavimo reikmèms.

Lietuvos miesty struktūras, su nedidelèmis išimtimis, galima pavadinti monocentrinèmis. Užstatymo tankio, gyventojų, darbo vietų, paslaugų ir kitais teritorinès koncentracijos požymiais dominuoja centrinè miesto dalis, o joje - miesto centras. Periferinè miesto dalis pasižymi mažiausia koncentracija. Kaip pasekmè tokị pat charakterị igauna transporto priemonių srautų, viešojo transporto maršrutų apkrovimas, pėsčiųų eismo intensyvumas (2 pav.). Neatsižvelgus i šiuos pasiskirstymus, sunku garantuoti, kad miesto modelis atitiks miesto funkcionavimo charakteri. Todèl anksčiau naudotą rajonavimo kriteriju - susisiekiamumo pẻsčiomis erdvès dydį - galètų pakeisti kitas, "vienodo" transporto darbo (ar susisiekimo procesu intensyvumo) kriterijus. Todèl rajono dydis centro atžvilgiu kistų tokiu pat mastu kaip ir 2 pav. miesto veiklos koncentracija.

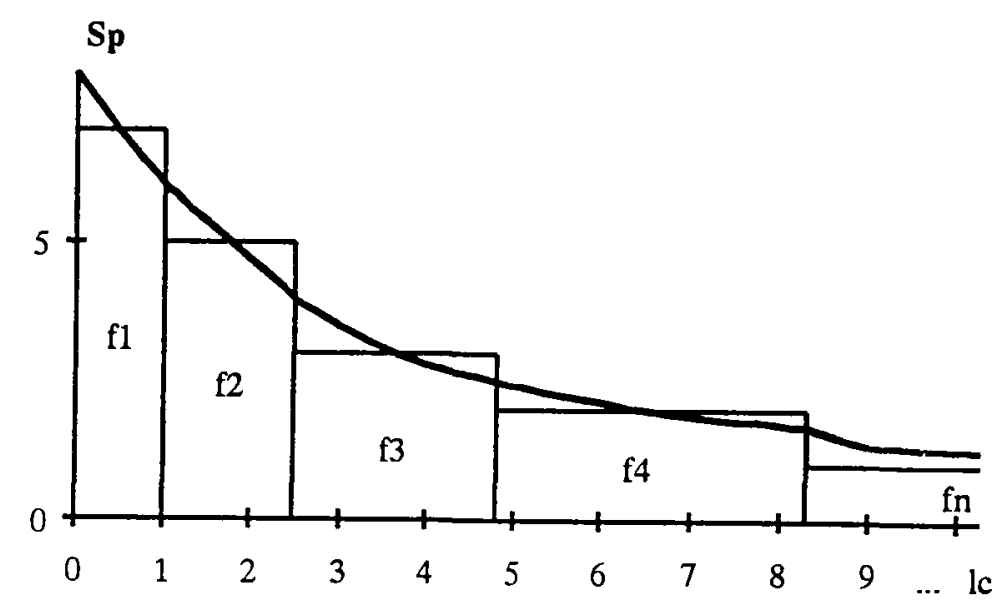

2 pav. Transportinių rajony̨ dydžių nustatymo principas

A: pagal transporto darbo apimtị (kel. km, aut. $\mathrm{km}$ ir pan.),

Sp - transporto priemonių srauty, viešojo susisiekimo maršruty apkrovimo pésčiujų eismo ir pan. intensyvumo būdinga kreivé, $\mathrm{fn}$ - rajono dydis ir ju skaixius. Sąlyga: $\mathrm{f} 1 \cdot \mathrm{Sp} 1 \approx \mathrm{f} 2 \cdot \mathrm{Sp} 2 \approx \ldots \approx \mathrm{fn} \cdot \mathrm{Spn}$

Tačiau modeliuojant ịvairius susisiekimo procesus, ypač gatvių apkrovimą, pasirodè, kad šis kriterijus nèra geriausias. Paaiškèjo, kad modeliavimo tikslumas daugiau priklauso nuo transportinių rajonų sąlyginių centrų padéties gatvių tinkle ir tų centrų skaičiaus, negu nuo rajono konfigüracijos ar jo ploto. Be to, svarbiausias veiksnys yra gatviu tinklas, i kuri gravituoja tiek automobiliai, tiek péstieji (pésčiuju eismas i viešojo susisiekimo stoteles ar pagrindines komunikacines šio eismo trasas). Todèl konkrečias rajonų ribas turi nulemti gatvių tinklo geometrinè konfigūracija ir gatvių ịtakos izolinijos. 
Iš esmès neatmetant šiu argumentų, susisiekimo planavimui svarbiausiu kriterijumi lieka transportinių rajony dydis:

Pima, didinant planuojamoje teritorijoje rajonų skaičų, auga jų funkcinio vienalytiškumo tikimybè ir miesto modelis vis labiau atitinka realią situaciją.

Antra, toliau ekstrapoliuojant, galima būtų pereiti prie nepaprastai mažu rajonų arba jų visai atsisakyti. Pastaruoju atveju susisiekimo poreiki apibūdintų reprezentatyvi atskirų gyventojų, šeimų (namo) susisiekimo poreikių visuma. Ši visuma būtu pradinè ir pagrindinè susisiekimo reikmių informacinė bazé susisiekimui planuoti ir,priklausomai nuo uždavinių tipo, duomenys galètų būti agreguojami bet kuriuo norimu mastu. Toki metodą pirmieji, turimomis žiniomis, pradejo naudoti Montrealio politechnikos mokyklos Transporto centro mokslininkai. Pagrindinis šio metodo privalumas - iš esmés nebereikia papildomų susisiekimo proceso tyrimų, vadinamųju "antrinių" duomeny apie keleivių, transporto priemonių srautus, jų intensyvumą, dinamiką ir t.t.. Jie gaunami gatvių ir kituose susisiekimo tinkluose modeliuojant susisiekimo procesus, kuriems nustatyti natūroje reikia daug laiko ir lešųu, ypač dideliuose miestuose. Tačiau iškyla modeliavimo rezultatų verifikavimo problema, kurią minètas Transporto centras išsprendžia per reprezentatyvią atskirų gyventojų apklausos duomenų visumą.

Trečia, kuo didesnis rajonı̨ skaičius, tuo didesnis ir susisiekimo procesų modeliavimo tikslumas, tačiau didesnè darbų apimtis ( 3 pav.).

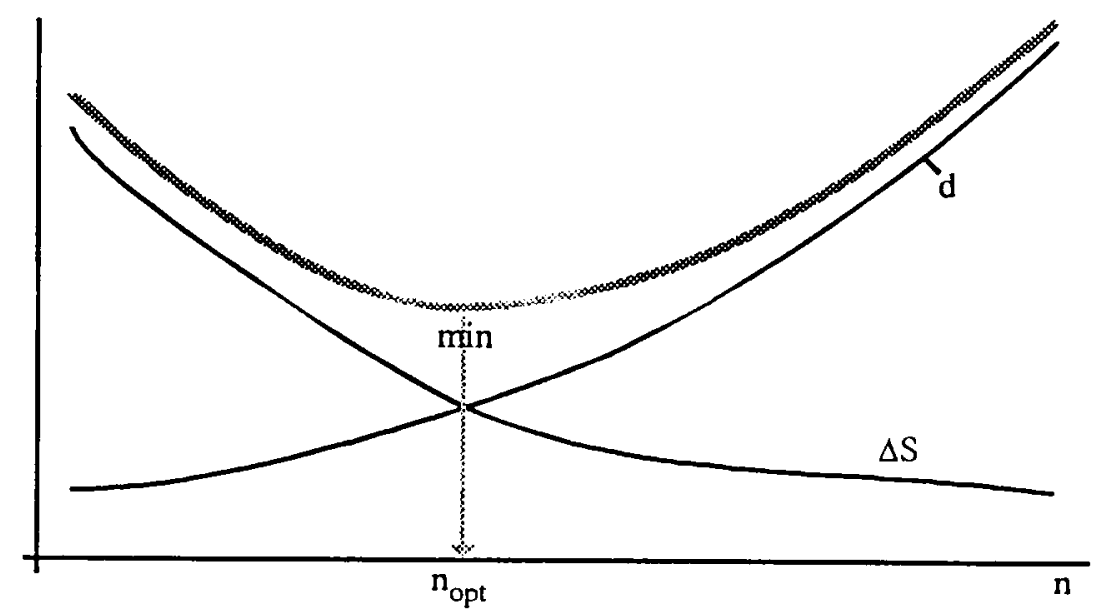

3 pav. Transportiniy rajonų skaičiaus optimumas

d - susisiekimo procesu modeliavimo darbų apimtis,

$\Delta \mathrm{S}$ - modeliavimo paklaida,

$\mathrm{n}_{\mathrm{opt}}$ - optimalus rajony̨ skaičius

Miesto ar kitos planuojamos teritorijos padalinimo i transportinius $\mathrm{x}$ dydžio rajonus nustatymas teoriškai yra lengvai išsprendžiamas optimizavimo uždavinys. Tačiau kol kas praktinè nauda negarantuota, nes maža adekvačios socialinès, demografinès, urbanistinès ir kitokios 
susisiekimo planavimui reikalingos informacijos (tai ne vien oficialios valstybinès statistikos institucijų veiklos trūkumas, bet ir natūrinių reguliarių tyrimų problema).

Pagrindine informacinio aprūpinimo problema laikytina tai, kad oficialioji statistiné informacija, kurią renka, kaupia ir apdoroja statistikos institucijos, yra visiškai nepritaikyta miesty susisiekimo sistemų planavimo (tas pats ir miesty planavimo) reikmèms. Administracinè miesto, šalies rajono ar jo apylinkès teritorija yra mažiausi statistikos objektai. Todèl, geriausiu atveju, sią informaciją galima panaudoti aukštesnio negu miesto ar jo įtakos zonos rango susisiekimui planuoti. Turinio prasme oficialioji statistika teikia ne daugiau kaip 3-5\% reikalingos informacijos. Pastaraisiais metais teikiamų duomenų sąrasas pasipildé tik miestų ir rajony automobilizacijos duomenimis.

Ivairios valstybinès institucijos, savivaldybés disponuoja ịvairiarūše tarnybine informacija, kuri galètụ būti panaudota susisiekimo planavimo reikmèms. Tačiau ji yra nesusisteminta, viešai neskelbiama ir jos gavimas komplikuotas.

Nèra nè vienos institucijos, kurios nuolatinès veiklos objektas būtų pagrindinių susisiekimo procesų, kurie nèra oficialios ir privalomos statistikos objektas, tyrimas ir duomenų kaupimas bei sisteminimas. Tik pastaruoju metu atsirado tokios veiklos užuomazgu savivaldybių transporto ar panašiose tarnybose. Tačiau jų galimybès nepaprastai mažos.

Lietuvoje susisiekimo sistemy tyrimai V.Šeštoko iniciatyva pradèti 1962-1965 metais. Tačiau iki šol tiriama tik iškilus konkrečiai reikmei, dažnai vienkartiniam panaudojimui ir tik dalis tyrimų yra sisteminiai. Periodai nereguliarūs, naudojamos neidentiškos metodikos, neišlaikomas turinio perimamumas. Todèl tyrimu duomenys ne visada palyginami ir tinkantys susisiekimo procesų dinamikai nustatyti.

Susisiekimo planavimo patirtis palaipsniui suformavo tam tikrą būtinos informacijos įvaizdị, tačiau jis neigijo privalomumo. Todèl nesant susisiekimo tyrimy standarto (ar kitu pavadinimu tyrimus reglamentuojančio dokumento), praktiškai egzistuoja galimybẻ suformuoti bet kokią tyrimų programą turinio, apimties detalumo, tyrimų laiko požiūriais. Atsiranda didelè tikimybè, kad:

tyrimų rezultatai nepalyginami su retrospektyvine informacija dẻl metodikos skirtumų, tyrimy laikotarpių principinio nesutapimo;

tyrimai yra nereprezentatyvūs;

tyrimų turinys ir apimtis yra perkrauti nevertingų, antraeilių iliustratyvių ir greitai senstančị duomenų.

Ši tikimybẻ gali padidèti ypač dabar, kada susisiekimą planuojanti institucija miesto bendrajam ar specialiajam planui sudaryti atrenkama konkurso keliu, ypač jeigu konkurso sąlygose svarbiausiu kriterijumi laikomas lěšų dydis darbui atlikti. 
Susisiekimo procesų tyrimai reikalauja daug darbo, lěšų, kurių kaip visada trūksta. Tai svarbiausias veiksnys, reguliuojantis tyrimų programą. Todèl gana dažnai susidaro prieštaringa situacija: dèl léšų trūkumo neįmanoma sudaryti reikalingos tyrimu programos ir jos realizuoti, o susisiekimo planavimo specialistams profesinè ir juridinė atsakomybė išlieka.

Dar vienas argumentas, kuris skatina kuo greitesnị susisiekimo tyrimų standartų parengimą. Standartais nustatyta minimaliai būtina tyrimų apimtis ir turinys padẻtų sumažinti léšų poreikị. Tik tais atvejais, kai miesto funkcijos yra specifinès, ar yra kitu ypatybių, tyrimai gali būti papildyti.

Informacinis aprūpinimas turètų būti nepaprastai platus. Praktiškai tenka atrinkti tai, kas neišvengiamai būtina, t.y., minimaliai būtiną informacinị aprūpinimą.

Dabartinè susisiekimo planavimo sukaupta patirtis leidžia teigti, kad minimaliai būtino informacinio aprūpinimo turinys turètų būti toks:

A. Susisiekimo sistemos elementai:

1. gyventojai (gyventojų skaičius; socialinè demografinè struktūra; užimtumas; gaunamos pajamos);

2. transporto priemonès (skaičius; tipai; nuosavybe்; amortizacijos laipsnis; panaudojimo laipsnis; kuro rūšys ir sunaudojimas);

3. susisiekimo techninè infrastruktūra (pèsčiujų, dviračių, automobilių ir kitu transporto priemonių komunikaciniai tinklai ir jų parametrai; sankryžos ir kiti transporto mazgai bei ju parametrai; autobusų, geležinkelio stočių, uostų, aerouostų techniniai ir funkciniai parametrai; garažai ir parkingai, jų tipai, talpa);

4. viešojo keleivių susisiekimo infrastruktūra (maršrutai, stotelès, darbo grafikai);

5. eismo valdymo ir reguliavimo infrastruktūra (ženklai, šviesoforai, markiravimas, reguliavimo techninès sistemos).

B. Aplinka, kurioje funkcionuoja susisiekimo sistema:

1. žemè (paskirtis, nuosavybè, veiklos apribojimai, ekologinis jautrumas);

2. miestas, planuojamoji teritorija ( plano ir funkcinè struktūra, užstatymo tipas, užstatymo tankis, darbo victos ir paslaugos);

3. eismo režimas (eismo ir parkavimo segregacija, apribojimai, draudimai, prioritetai).

C. Susisiekimo poreikis:

1. gyventojų judrumo ir ryšių bei kitų parametrų visuma.

D. Susisiekimo sistemos funkcionavimas:

1. pésčiųjų ir dviratininkų srautai (intensyvumas, greitis, tankis);

2. viešojo transporto keleivių srautai (intensyvumas, greitis, tankis pagal maršrutus, jų tipus), transporto priemonių užpildymas; 
3. privačių lengvuju automobilių vainotojų ir keleivių srautai (intensyvumas, greitis, tankis, automobilių užpildymas);

4. taksi automobilių keleivių srautai (intensyvumas, greitis, tankis pagal taksi tipus; taksi automobilių užpildymas);

5. transporto priemonių srautai (intensyvumas ir manevrai sankryžose, greitis, tankis; srauty struktūra);

6. transporto priemonių parkavimas (parkuojamų transporto priemonių skaičius, trukmé pagal parkavimo vietų ir transporto priemonių tipus).

E.Susisiekimo sistemos funkcionavimo pasekmès:

1. eismo nelaimès (eismo nelaimių skaicius, pasiskirstymas erdvèje ir laike pagal eismo nelaimių tipus);

2. triukšmas (linijinių ir kitụ šaltinių triukšmo ekvivalentinis lygis, šaltinių struktūra);

3. oro tarša (linijinių ir kitų šaltinių taršos mastas, koncentracija, šaltinių struktūra);

4. barjero efektas (pèsčiujų eismo erdvès diskomforto lygis);

5. teritoriju poreikis, teritorijų naudojimo ir funkcijų pokyčiai.

\section{F. Susisiekimo kaina:}

1. socialinè kaina (keleivių ir vainuotojų, pėsčiujų, dviratininkų sugaištamas kelionèms laikas);

2. energetinè kaina (sunaudojamas energijos kiekis, rūšys);

3. vartojamoji kaina (vartotojų išlaidos viešajam transportui, tarifai, lengvatos; išlaidos privačiam transportui, mokesčiai, rinkliavos, lengvatos);

4. valstybès, savivaldybių ił̌laidos ir pajamos (investicijos ir eksploatacinès isłaidos techninei infrastruktūrai, dotacijos; ịplaukos iš mokesčių, rinkliavų, paslaugu);

5. privačių juridinių ir fizinių asmenų investicijos ị susisiekimo sistemą.

Informacinio susisiekimo planavimo aprūpinimo blokai galètų būti atitinkamo duomenų banko struktūrinès dalys, kurias, esant poreikiui, papildytų kitų specializuotų miesto duomenų banku informacija.

\section{Diagnozès procedūra}

Diagnozè - tai ne vien susisiekimo sistemos būklès konstatavimas, bet ir įvertinimas, problemy nustatymas bei susisiekimo procesų desningumų ir matematinių modelių sudarymas.

Diagnozè turi apimti visus tuos aspektus, kurie sudaro informacinio aprūpinimo visumą: susisiekimo sistemos elementus, aplinką kurioje sistema funkcionuoja, pasekmes ir susisiekimo kainą. Tai gerokai platesnis analizés ratas negu tradiciniame susisiekimo planavime.

Labai mažas démesys buvo skiriamas aplinkai, kurioje funkcionuoja susisiekimo sistema. Miestas su jo plano ir funkcine infrastruktūra buvo traktuojamas kaip neliečiamas fonas, bet ne kaip 
aplinka, kuri formuoja konkretų susisiekimo poreikį. Urbanistiniai susisiekimo poreikio veiksniai negalèjo tapti argumentu miesto struktūrų transformavimui, nes determinuotas miesto generalinis planas iš esmès nenumatè tokių pertvarkymų galimybių. Be to, miestu generalinių planų sudarymo principai nenumatè miesto, kaip visumos, ir jo susisiekimo sistemos integruoto planavimo.

Savaime aišku, kad anksčiau nebuvo aktuali žemès nuosavybès analizè. Teritorijos susisiekimo reikmèms buvo skiriamos be jokių apribojimų, išskyrus tuos atvejus, kai iškildavo pastatų griovimo reikmè miesto centre ir senamiestyje bei kitose svarbiose vietose. Žemè neturéjo vertès, todèl ir susisiekimo planavime teritorijos poreikis nebuvo esminis analizes objektus ir susisiekimo sistemos ivertinimo kriterijus.

Rinkos ekonomika, privati žemès nuosavybè iš esmès keičia determinuotą miesto planavimą ir suteikia daug laisvès. Atsiranda privati iniciatyva ir to pasekmè -vis didesnè savaiminio, t.y., neplanuoto miesto struktūrų transformavimo procesų tikimybè. Tai žemès naudojimo, funkcijų pokyčiai, kuriuos nulemia susisiekimo sistemos funkcionavimo kokybè ir nauju stambiu komunikacinių liniju atsiradimas. Lietuvoje tai praktiškai nenagrinèta sritis, nors tokie procesai vyko ir anksčiau, nežiūrint to slopinimo, kurị daré miesto generalinio plano realizavimo griežta kontrolè. Planavime tai labai svarbūs procesai, nes jie pakeičia susisiekimo poreiki laike ir erdvèje.

Svarbiu diagnozès objektu tampa miesto transporto priemoniu parkas. Jo struktūra, panaudojimo laipsnis ir raidos dinamika atspindi susisiekimo galimybių pokyčius.

Tradiciniame susisiekimo planavime pagrindinis dèmesys buvo skiriamas sistemos funkcionavimo analizei: gatvių tinklo laidumo, viešojo keleivių susisiekimo sistemos pervežamosios galios, automobiliu parkavimo intensyvumo ir t.t. analizei. Negalima tvirtinti, kad pasekmiu analize buvo pamiršta. Šitie dalykai buvo analizuojami, tačiau dažniausiai iliustratyviai ir ne vien del faktiniy tyrimų stokos (pavyzdžiui, vienintelis transporto triukšmo žemèlapis Vilniuje sudarytas $1980 \mathrm{~m}$ ), bet ir dèl to, kad pasekmių analizè ir pasiūlymai labai retai igaudavo praktinio realizavimo galimybę. Todèl funkcionavimo pasekmių analizè netapo vienu iš svarbiausių planavimo sprendinių kokybès kriterijumi, nes ir seniau galiojusiose normose tai nebuvo numatyta.

Susisiekimo kaina neturèjo susisiekimo poreikio ir galimybių bei sistemos funkcionavimo reguliatoriaus vaidmens. Bet kurie finansiniai dalykai buvo Valstybinis plano komiteto (miestuose - Plano komisijos) kompetencijoje ir jam priklausè sprendžiamojo balso teisé, kuri galiojo nepriklausomai nuo susisiekimo sistemos sprendiniy argumentacijos. T.y., susisiekimo planavimo funkciniai sprendiniai buvo atskirti nuo susisiekimo kainos. Dabar politinè ir socialinè situacija kita, tačiau miestų susisiekimo planavime kaina dar neịgijo deramos reikšmès.

Susisiekimo sistemos būklès analizè yra poreikio ir galimybių analizè. Priklausomai nuo disproporcijos masto, turésime didesnių ar mažesnių funkcinių, pasekmių ir kainos problemų. Tarp šių problemų nèra tiesioginès priklausomybès. Jos gali sutapti visiškai ar dalinai, prieštarauti viena kitai. "Normali" susisiekimo sistema gali funkcionuoti be problemų, tačiau jos 
funkcionavimo pasekmès gali būti problema. Pasekmių problema neegzistuos biotransporto mieste. Esant mišriai sistemai, pasekmių minimumą gali garantuoti tik didelè susisiekimo kaina.

Todèl iškyla metodinè problema: kaip identifikuoti problemų egzistavimą ir kaip ịvertinti sistemos bendrą kokybę.

Funkcinių ir pasekmių problemų identifikavimui buvo naudojamas norminis metodas. Jeigu poreikio ir galimybiy disproporcijos matu laikysime faktini bet kuri susisiekimo proceso ar pasekmiy rodiklị $d_{f}$, o normini to pačio rodiklio dydị $d_{n}$ riba, tai visi $d_{f}>d_{n}$ atvejai interpretuojami kaip problema, o $\mathrm{d}_{\mathrm{f}} \leq \mathrm{d}_{\mathrm{n}}$ rodo, kad problema neegzistuoja.

Tai paprastas ir patogus būdas. Tačiau jo silpnoji vieta - labai platus interpretacijos diapazonas ir dèl to didelé subjektyvumo tikimybè. T.y., tas pats konkretus faktas ar sprendinys gali igauti prieštaringus vertinimus.

Ne visiems susisiekimo funkcionavimų ir pasekmį rodikliams gali būti nustatyta norma, nes tai prieštarauty elementariai logikai (pavyzdžiui, nustatyti eismo nelaimių normą, nebent ji būtụ lygi 0). Todèl $d_{n}$ pakeisdavo kitų šalių analogai arba subjektyviai nustatyti dydžiai.

Norminis metodas iš esmès netinka susisiekimo kainai nustatyti.

Samprata, kad susisiekimo poreikio ir galimybių disproporcija yra normali sistemos būklè ir kad tos disproporcijos funkcine ir kainos prasme yra susisiekimo poreikio ir sistemos veiklos reguliatorius, reikalauja kiek kitokio požiūrio ị problemų identifikavimą ir sistemos įvertinimą.

Miesto mastu problemų identifikavimas iš esmés yra alternatyvus: yra arba nèra ir kokiu mastu, palyginus su norminiais rodikliais.

Lokalinès ir atskirų gyventojų grupių problemos gali igauti kiek kitokią prasmę - nors formaliai tai problema, iš tikrujų tai gali būti susisiekimo poreikio ar susisiekimo procesu reguliavimo priemonè, kuriai alternatyvos ne visada gali būti surastos. Todèl, ne visada jos gali būti palyginamos ar siejamos su bendrosiomis miesto susisiekimo problemomis, ǐ̌skyrus pasekmių rodiklius.

Norminis metodas galètų būti pagrindinis visos susisiekimo sistemos, jos posistemés ar elementų veiklos problemų identifikavimo būdas pagal vieną iš $n$ norminių rodiklių, kurių visuma nusakytų funkcinių pasekmių ir kainos problemų mastą.

Norminių rodiklių sąrašo ir jų skaitinių reikšmių nustatymas nèra vien specialistų, planuojančių susisiekimą, reikalas. Todèl labai svarbu, kad šis sąrašas ir skaitinès reikక̌mès igautu valstybès standartų reikšmę. Tai padètų rasti kompromisą tarp atskirų institucijų vykdomos politikos kraštutinumų (aplinkos apsaugos, higienos institucijı̨ politika - maksimalūs reikalavimai, viršijantys analogiškus išvystytų šaliu reikalavimus, o savivaldybès statybos ir urbanistikos, susisiekimo ir kitos ministerijos kol nenustaté nauju reikalavimu) tarp teoriškai objektyviai pagrịstų ir praktiškai neįmanomų îvykdyti reikalavimų.

Sudarant norminių rodiklių sąrašą ir nustatant jų skaitinius dydžius, papildomai turètų būti atsižvelgta ị tokius susisiekimo planavimui būtinus dalykus: 
turi būti įvertintas miesto dydis, jo funkcijos; miesto atskiros dalies, rajono ar sklypo paskirtis, jos jautrumas eismo poveikiui,

sąrašas ir skaitiniai dydžiai diferencijuotini miesto, lokaliniam ir atskiru gyventoju grupių lygiams; miesto veiklos ciklams,

funkcionavimo rodikliams numatytina galimybé įvertinti jų tarpusavio santykinę reikšmę,

rodiklių sąrašas ir jų skaitinès reikšmès turètų būti periodiškai keičiamos, atsižvelgiant ị pakitusias ekonomines ir kitas galimybes, socialinius poreikius ar keičiantis vertybių sampratai.

Diagnozès procedūra turi ir kitų aspektų: priežasčių bei veiksnių analizę, susisiekimo procesų, funkcionavimo pasekmių ir kainos dėsningumy nustatymą. Aišku, kad nežinant pagrindiniu priežasčị ir veiksnių, susisiekimo planavimas, geriausiu atveju, bus paviršutiniškas ir formalus. Be šito neįmanoma tikslesnẻ prognozè, matematinių susisiekimo sistemos modelių sudarymas, o po to ir variantinis planavimas.

Matematiniai susisiekimo sistemos modeliai, taip pat atitinkama programinè ịranga - tai kokybiškai naujas susisiekimo planavimo instrumentas. Tačiau įvairios priežastys iki šiol neatvèré didesnių šio instrumento panaudojimo galimybių, o tai yra pati svarbiausia planavimo problema. Viena iš objektyvių priežasčių - didelès pradinès išlaidos. Savivaldybès paprastai ju neturi, privačios firmos kol kas nèra suinteresuotos, nes susisiekimo planavimas bei jam reikalinga programinè įranga yra specifinè ir nèra "masinio" naudojimo Lietuvoje produktas. Užsienio šalių programinès įrangos pasiūla yra pakankamai didelé, nors ją reikètų modifikuoti mūsų sąlygoms (analogiška būtinybè iškilo prieš dešimtmetị, bandant taikyti susisiekimo modelių programinę irangą besivystančiose šalyse) [3]. Praktiškai konkurencija užsienio šaliu programinei ịrangai yra neįmanoma. Jos ir nereikètų, jeigu dabartiné situacija Lietuvos firmų nedarytų nekonkurentabilių. Netiesioginis pavyzdys - "Vilniaus miesto transporto generalini planą" daro Anglijos firma WS Atkins International limited. Žinoma, vargu ar galima tai lyginti su praẻjusiais dešimtmečiais, kada galiojo atviras protekcionizmas. Tada visų, didesnių kaip 250 tūkst. gyventojų, miestų vadinamąsias kompleksines miesto transporto schemas ekspertuodavo Kompleksinis transporto problemų institutas Maskvoje. Ekspertizès sèkmę garantuodavo tik šio instituto rekomenduotos programinès įrangos panaudojimas ir atitinkama konsultacija su jų specialistais.

Susisiekimo planavimo modeliai sudaro gana sudètingą sistemą. Šiuo metu galima kalbèti apie šią sistemą kaip tikslą, nes kol kas yra pirmosios kompiuterizuotos sistemos užuomazgos. Taip susiklostė susisiekimo planavimo metodikos raida, kad praktiškai kiekvienas specialistas, dirbantis šioje srityje, stengèsi apsiriboti tokia veiklos sfera, kurią įmanoma aprèpti vienam. Todèl dauguma susisiekimo planavimo modelių yra autonominiai ir jų tarpusavio ryšys yra neracionalus.

Susisiekimo planavimo modelių visumos struktūia pateikta 4 pav. Ji sudaryta remiantis susisiekimo priežasčiu, susisiekimo procesų ir jų pasekmių bei kainos ryšiais. 
Silpniausia, praktiškai nenagrinèta grandis šioje modelių sistemoje - kainų modeliai. Tai ne tik tos kainos, kurią tenka sumokèti gyventojams ir visuomenei už susisiekimo sistemos egzistavimą bei jos paslaugas, bet ir už sistemos funkcionavimo pasekmes bei susisiekimo procesų reguliavimą, t.y., kokio dydžio tarifai, mokesčiai, rinkliavos ir pan. ịtakoja susisiekimo poreiki.

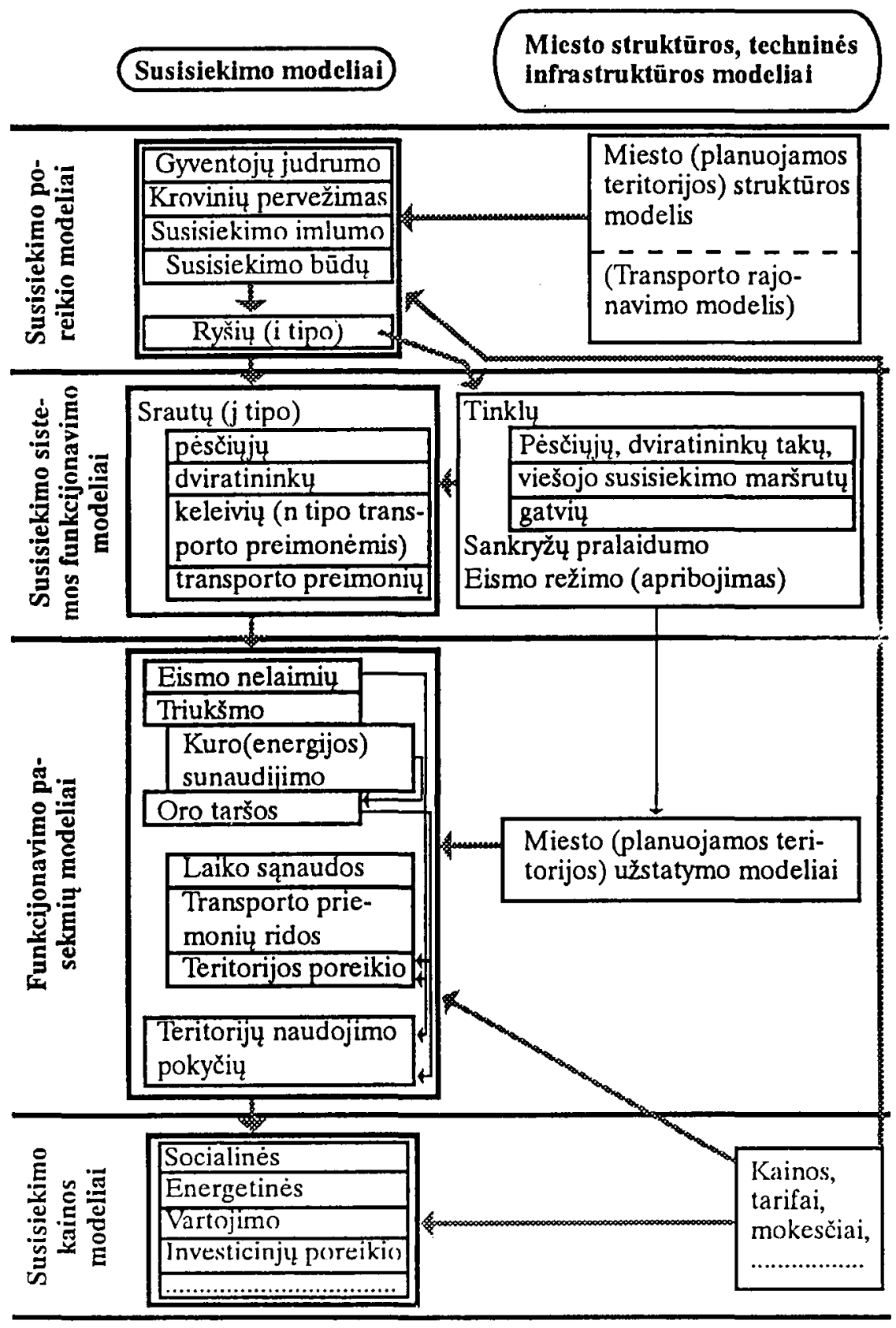

4 pav. Susisiekimo planavimo modelių visumos struktūros schema 
Prognozès dalis - iprasta ir neišvengiama procedūra, naudojant bet kokią susisiekimo planavimo metodiką. Paminètinos kelios pagrindinès prognozès ypatybès. Pirma, susisiekimo planavimui reikalinga visų urbanistinių, socialinių, demografinių ir kitų procesų prognozè. Todèl šis planavimas yra priklausomas nuo kitų sričių ir čia atsiranda antroji ypatybè - susisiekimo reikmių ir galimybių prognozès tikslumas praktiškai negali būti tikslesnis negu minètas pagrindas.

Anksčiau, komandinés ekonomikos sąlygomis, prognozė formaliai nesudarẻ ypatingų ir sudètingesnių problemų. Ne tik pagrindinius, bet ir kitus detalius prognozès rodiklius (miesto gyventojų skaičių, užimtumą, darbo vietų skaičių, veiklos profilį, gamybos apimtį ir t.t.) teikè Valstybinis plano komitetas ir jo struktūros. $\mathrm{O}$ tai buvo savotiškas įstatymas miesto generalinio plano sudarytojams, tarp jų ir susisiekimo planuotojams. Determinuotas generalinis planas teikè, atrodytu, didelę tikslios prognozès tikimybę. Tačiau praktiškai niekada konkretiems metams prognozès nepasitvirtindavo. Pavyzdžiui, prognozuojamas didžiausiuose miestuose gyventojų skaičius visada pasirodydavo mažesnis negu faktinis. Jau vien tai rodo, kad faktinis susisiekimo sistemos darbas viršydavo planuojamaji. Niekada nepasitvirtino susisiekimo sistemos techninès infrastruktūros plètojimo, automobilizacijos lygio augimo tempai ir kita.

Sąlygini prognozès paprastumą anksčiau lèmè ir tai, kad susisiekimo kaina tiesiogine ir perkeltine prasme, nebuvo traktuojama kaip svarbesnis veiksnys, įtakosiantis susisiekimo procesus ateityje.

Siuo metu vargu ar galime tvirtinti, kad turime rimtą pagrindą prognozei. Geriausiu atveju - tik platų prognozès spektrą - nuo optimistinès iki pesimistinès - su vienoda prognozès pasitvirtinimo tikimybe. Jeigu po kelerių metų socialinè ekonominè raida taps labiau prognozuojama, tai anksčiau buvusio vadinamojo planinio ūkio (lygiai taip pat ir miesto plètros) determinuotumo neliks. Todèl tikètina, kad pagrindine prognozès baze taps retrospektyvinio periodo dèsningumai ir tendencijos, neteks prasmès labai detali, kaip anksčiau, prognozè, ypač tolimesnei ateičiai.

Dèl šiu priežasčių susisiekimo poreikio, susisiekimo sistemos funkcionavimo, pasekmių ir kainos bei susisiekimo galimybių prognozès ir problemų nustatymo pagrindiniu objektu turi tapti netolimos ateities raida. Tolimesnei ateičiai prognozès detalumas turi būti gerokai mažesnis, tik svarbiausiais aspektais.

Dar viena svarbi prognozès dalies ypatybė: griežtai kalbant, susisiekimo poreikių ir sistemos funkcionavimo bei kitų dalykų prognozè daugeliu atvejų yra hipotezé. Miesto bendrajame (anksčiau generaliniame) plane numatyta miesto teritorinè ir funkcinè struktūra taip pat yra hipotezè (formaliai tai yra nustatytas plètros tikslas), kurią patikrins laikas. Todèl, remiantis susisiekimo procesų ir miesto plètros prognoze, gali būti, o kai kada tai bus neišvengiamai būtina, numatytos alternatyvos. T.y., ne vienareikšmè, o alternatyvi prognozè. 


\section{Susisiekimo sistemos plètojimo tikslai}

Plètojimo tikslus galima pavadinti "noru" turèti tokią susisiekimo sistema, kuri garantuoty "gerą" kokybę. Kokią turime, konstatuoja diagnozès dalis, kokia gali būti pasyvios raidos atveju prognozè. Diagnozès ir problemu palyginimas rodo, koki kelią, perkeltine prasme, turi nueiti susisiekimo sistemos plettojimas, kol pasiektų norminius susisiekimo rodiklius.

Ivertinant šių rodiklių visumos interpretavimo atvejus, susisiekimo sistemos plètojimo tikslai galèty būti tokie sistemos tipai:

primityvi sistema, kurios vienintelis tikslas yra pervežti keleivius (krovinius) tam skiriant turimus visus išteklius ir absoliučiai nekreipiant dèmesio ị sistemos funkcionavimo kokybę, pasekmes, socialinę kainą;

minimaliai būtina sistema, kuri garantuoja pagrindinių susisiekimo poreikių (visu pirma determinuotų darbo ir kitų panašių kelionių) realizavimą sąlygomis, artimomis norminèms funkciniu požiūriu, bet nepriimtinomis dèl pasekmių;

norminè sistema, kuri garantuoja norminius perspektyvinio periodo funkcinius, pasekmiy rodiklius, o sistemos kaina yra priimtina gyventojams ir miestui;

hipertrofuota sistema, kurios pletojimas yra susijęs su vieno ar keliu tikslų arba atskiros transporto rūšies privalumų absoliutinimu ir kada ekonominių bei kitų apribojimų beveik nèra (pvz. lengvojo privataus automobilio ar viešojo transporto, biotransporto ir t.t. privalumų absoliutinimas);

harmoninga arba darni funkcionavimo, pasekmių ir kainos prasme susisiekimo sistema.

Lietuvos miesty susisiekimo sistemų plètojimo tikslus per artimiausią dešimtmetị, geriausiu atveju, gali būti tik sistema, panaši ị minimaliai būtiną. İvertinant spartụ automobilizacijos lygio kilimą, nepaprastai mažas ekonomines miesto infrastruktūros ir viešojo susisiekimo plètojimo galimybes, sistemos tikslas galètų būti ir status quo, t.y., išsaugoti dabar turimą lygi, o tai nẻra taip paprasta, ypač dèl miestų teritorinès plètros, miestų struktūrų ypatybių.

Nepriklausomai nuo to, kaip bus suformuluoti sistemos plètros bendrieji tikslai, jie yra tik preliminarūs, dalinai abstraktūs ir nepatikrinti konkretaus miesto urbanistineje aplinkoje, susisiekimo sistemoje. Pastarieji du dalykai visada turi inercijos. Staigi susisiekimo sistemos veiklos transformacija fiziškai neįmanoma, o ir psichologiniu požiūriu nepriimtina. Gyventojai būna prisitaikę prie susisiekimo sistemos ypatybių ir bet kuris pokytis turi pereiti tam tikrą adaptacijos periodą.

Todè autorius mano, kad susisiekimo sistemos plètros norminiai dydžiai yra tik orientyras. Plètros tikslus, daugeliu atvejų, teisingiau būtų formuluoti kaip procesą, kuriuo siekiama:

sumažinti susisiekimo poreikị;

garantuoti ne blogesnị negu norminị susisiekiamumą, sistemos funkcionavimo patikimumą; 
sudaryti kuo didesnę susisiekimo būdų pasirinkimo laisvę, kelionių komforto sąlygas;

minimizuoti miesto gyventojų bendras laiko sąnaudas visiems veiklos ciklams;

minimizuoti susisiekimo sistemos taršos dydị ir poveiki gyventojams bei aplinkai;

garantuoti sąlygas, kurios sumažintų pesčiujjų, keleivių ir transporto priemonių eismo nelaimių tikimybę;

sumažinti motorizuotų transporto priemonių eismui, stovejjimui ir saugojimui teritorijos poreikị;

minimalių išlaidų ar minimalios susisiekimo sistemos veiklos kainos.

Šiuos tikslus galima pavadinti bendraisiais visos miesto susisiekimo plètojimo tikslais. Juos būtina papildyti lokaliais laiko ir erdvès bei atskiru gyventoju grupių interesų patenkinimo tikslais, arba specialiaisiais tikslais.

Bendrieji ir specialieji tikslai susisiekimo planavimo patogumui gali būti formuluojami pagrindinių tikslo funkcijų ir apribojimų sistema.

Socialinis tikslas - minimizuoti planuojamos teritorijos gyventojų bendras laiko sąnaudas $\mathrm{H}$ (gyv./val) visoms reikmèms ir visiems veiklos ciklams bei visais susisiekimo būdais ar priemonèmis:

$$
\mathbf{H}=\sum_{1}^{b} \sum_{1}^{h} \sum_{1}^{i j} \sum_{1}^{g} \frac{m_{g} N_{g} l_{i j}}{V_{b}}=\min .
$$

Funkciniai tikslai - minimizuoti visų motorizuotų transporto priemonių ridą $A R$ ir bendras jų laiko išlaidas $\mathrm{AH}$ planuojamosios teritorijos gatviu tinkle:

$$
\mathbf{A R}=\sum_{1}^{b} \sum_{1}^{h} \sum_{1}^{i j} A_{b} \cdot l_{i j}=\min
$$

arba

$$
\begin{aligned}
& \mathbf{A R}=\sum_{1}^{b} \sum_{1}^{h} \sum_{1}^{i j} \frac{m_{b} \cdot N_{b}}{q_{b}} \cdot l_{i j}=\min . \\
& \mathbf{A H}=\sum_{1}^{b} \sum_{1}^{h} \sum_{1}^{i j} \frac{A_{b} \cdot l_{i j}}{V_{b}}+\sum_{1}^{b} \sum_{1}^{n} A_{b} \cdot S_{n} \cdot t_{n}=\min
\end{aligned}
$$

arba $\quad \mathbf{A I I}=\sum_{1}^{b} \sum_{1}^{h} \sum_{1}^{i j} \frac{m_{b} \cdot N_{b} \cdot l_{i j}}{q_{b} \cdot v_{b}}+\sum_{1}^{b} \sum_{1}^{n} \frac{m_{b} \cdot N_{b} S_{n} \cdot t_{n}}{q_{b}}=\min$.

Aplinkosauginiai tikslai - minimizuoti transporto priemoniu su vidaus degimo varikliais sunaudojimo kuro ir elektros transporto energijos kiekị:

$$
\mathbf{E}=\sum_{1}^{b} \sum_{1}^{h} \sum_{1}^{i j} \frac{m_{b} \cdot N_{b} \cdot l_{i j}}{q_{b}} k_{r b}+\sum_{1}^{b} \sum_{1}^{n} \frac{m_{b} \cdot N_{b} \cdot S_{n} \cdot t_{n}}{q_{b}} k_{s b}=\min .
$$

Saugaus eismo tikslai - minimizuoti eismo nelaimių tikimybę: 
$E N=f\left(\sum_{1}^{b} A_{b h}, j, u\right)=\min$.

Urbanistinis tikslas - minimizuoti teritorijos poreiki transporto priemonių eismui, stovejjimui ir saugojimui:

$$
P=f\left(\sum_{1}^{b} A_{b}, m_{b}, A H\right)=\min
$$

cia: $\quad \mathrm{m}$ - gyventoju judrumas, kelionių sk. per laiko vieneta,

$\mathrm{N}$ - gyventojų skaicius,

$\mathrm{l}_{\mathrm{ij}}$ - kelioniu ilgis tarp $\mathrm{i}$ ir $\mathrm{j}$ rajonų,

$v$ - susisiekimo greitis,

1...b - susisiekimo būdai, transporto priemonès,

1 ...g - diferencijuotų susisiekimo poreikių ir galimybių gyventojų grupès,

1...h - susisiekimo ciklai,

q - transporto priemonès salono talpa arba salono užpildymas, kel.,

S - sankryžų skaicius,

t - sugaištas 1 transporto priemonès laikas sankryžose,

n - sankryžų tipai,

$\mathbf{k}_{\mathbf{r}}$ - kuro (energijos) sąnaudos $1 \mathrm{~km}$,

$k_{s}$ - kuro (energijos) sąnaudos 1 val.,

A - transporto priemoniu skaicius,

j - eismo juostų skaičius gatvėje,

u - gatvès užstatymo tipas.

H tikslo funkcija gali būti minimizuota ịvairiais būdais. Gyventojų judrumo, kelionès ilgio sumažinimas - tai miestų planavimo ir susisiekimo uždavinys, susijęs su polifunkcinès miesto struktūros formavimu; gyvenamujų ir darbo paslaugų vietų disociacijos mažinimu; racionaliu gatvių ir viešo transporto maršrutu tinklo formavimu. Greičio padidinimas iš principo ịmanomas mažinant susisiekimo poreikị lengvaisiais automobiliais ir didinant viešojo susisiekimo galimybes; suteikiant eismo prioritetą viešajam transportui sankryžose ir gatvių atkarpose, teisingai sudarant viešojo transporto eismo grafikus

AR tikslo funkcija minimizuojama tuo pačiu būdu kaip ir H funkcija. Papildoma galimybè didinti transporto priemonès salono užpildymą. Tokia galimybè iš esmès yra, efektyviausias būdas iš kitu šalių patirties - vadinamosios car pool sistemos skatinimas, teisè naudotis specialiomis viešojo transporto linijomis ir nemokéti ịvairių ịvǎiavimo, parkavimo mokesčių, jeigu lengvojo automobilio salonas užpildytas keleivių.

AH tikslo funkciją sudaro dvi dalys - laikas, sugaištamas kelionei $1_{i j}$ atstumu ir laikas, sugaištamas sankryžose, perèjose. Pirmojo démens minimizavimas tolygus $A R$, išskyrus greicio reguliavimą. Prastovos sankryžose gali būti minimizuotos (kartu padidintas susisiekimo greitis), 
jeigu bus sumažintas sankryžu, pèsčiuju perejų skaičius, t.y. retinamas gatvių tinklo tankis arba tam tiktu eismo erdvinè segregacija ir naudojamas racionalesnis sankryžų reguliavimo būdas.

Aplinkosauginiai arba neigiamy susisiekimo sistemos funkcionavimo pasekmių sumažinimo tikslai yra gerokai platesni, negu čia pateikta kuro ir energijos E tikslo funkcijos minimizavimas. Tačiau būtina pažymèti, kad vien transporto priemonèmis šios problemos negali būti išspręstos, isskyrus ekstreminį atveji - uždrausti visų motorizuotų transporto priemonių eismą mieste. Ekvivalentinį triukšmo lygi, automobilių išmetamų dujų kiekį pagrindiniais lemiančiais veiksniais yra eismo intensyvumas, greičio režimas, t.y., praktiškai visa tai, kas susiję su $H, A R, A H$ minimizavimu. Todèl siūloma įvertinti tik $\mathrm{E}$ tikslo funkcijos minimizavimą, papildomai įvertinanti galimybę reguliuoti sunaudojamos energijos kieki transporto politikos priemonẻmis, skatinančiomis racionalesnių transporto priemonių pirkimą ir naudojimą.

Saugaus eismo tikslų funkcija EN taip pat neapima visu šos problemos aspektų. Pagrindiniu aspektu susisiekimo planavime laikytinos sąlygos ir veiksniai, kurie gali būti eismo nelaimiu tikimybès reguliatoriai. Koreliacinè ir regresinè analizè parodè, kad pagrindiniai veiksniai yra eismo intensyvumas, gatvès apkrovimo lygis, t.y. eismo juostu pralaidumo išnaudojimo laipsnis, juostu skaičius, gatvès užstatymo tipai: vienpusis, dvipusis ar izoliuotas.

Analogiškai urbanistinị tikslą patogiau išreikšti tais statistiniais veiksniais, kurie lemia teritoriju poreikį $\mathrm{P}$ susisiekimo sistemos reikmèms.

Dalis susisiekimo sistemos plétojimo tikslu pateiktini bendrais arba lokaliniais apribojimais:

$$
t_{i j}=\frac{l_{i j}}{v_{b}} \leq t_{\max }
$$

$v_{\min } \leq v_{b} \leq v_{\max }$

$p_{\min } \leq \sum_{1}^{b} A_{b} \leq p_{\max }$ kelionès maksimalios trukmès apribojimas - tai vienas iškelionès komforto reikalavimu ivertinimas. $t_{i j}$ - tai ir socialine, ekonomine ir susisiekimo pèsčiomis fizinių galimybių kategorija. $t_{\text {max }}$ turètų būti susisiekimo standartų reglamentuota ir diferencijuota $g$ gyventoju grupèms ir b susisiekimo būdams (pésčiomis, dviračiu ir viešuoju transportu);

susisiekimo greičio apribojimai ịvertina ne vien standartinį maksimalu leistiną 60 , bet ir nuraminto eismo zonų $30,40 \mathrm{~km} / \mathrm{h}$ greiți, būtinybę ji reguliuoti eismo nelaimių tikimybei sumažinti, eismo pralaidumui padidinti, kompromiso būdu reguliuoti taršos dydị;

bendro transporto priemonių srauto koncentracijos gatvès, sankryžos "stop" linijos pjūryje ribojimas. $p_{\max }$ - maksimalus leistinas pralaidumas eismo technologijos ir saugaus eismo požiūriu arba saugomy tcritoriju režimui garantuoti. $p_{\min }$ - sąlyga tolygesniam pagrindinių esamų gatvių naudojimui; 


$$
\begin{aligned}
& A_{b}=0 \\
& q_{1 \min } \leq q_{1} \leq q_{1 \text { max }}
\end{aligned}
$$

$q_{2} \geq q_{2 \min }$

$i_{\min } \leq i \leq i_{\max }$

atskiro transporto priemonių tipo eismo draudimai erdvèje ir laike; viešojo transporto priemonių salono užpildymo apribojimai. q1 max kelionès fizinio ir psichologinio komforto riba. $\mathrm{q}_{1 \mathrm{~min}}$ - racionalaus energetiniu, oro taršos požiūriu užpildymo minimumas;

privačių lengvuju automobilių panaudojimo funkciniu, energetiniu ir oro taršos požiūriu užpildymo minimumas, neapmokestinamo ivažiavimo $\mathfrak{i}$ intensyvios traukos rajonus (centrą, senamiestį) ar $i$ kurortinius ir pan paskirties miestus bei neapmokestinamo parkavimo žemutinè riba;

viešojo transporto priemonių važiavimo laiko intervalo maršrute ar jų tinkle apribojimai. $i_{\min }-$ maksimali intervalo trukmé funkciniu, t.y. keleivių pervežimo pajėgumų arba socialinio minimumo ir viešajam transportui suteiktino funkcionavimo prioriteto prasme; $i_{\min }$ - minimali; intervalo trukmé pagal stotelès maksimalų pralaidumą, arba naujos dubliuojančios viešo transporto linijos reikmès sąlyga;

$$
\begin{array}{ll}
f_{g b} \leq f_{\max } & \text { susisiekimo sistemos vartotoju piniginių išlaidù apribojimas, } \mathbf{f}_{\max } \text { - } \\
& \text { maksimali } \mathrm{g} \text { grupès gyventojų vartojimo išlaidu dalis, tenkanti } \mathbf{b} \\
& \text { susisiekimo būdui ar transporto priemonei; } \\
F_{g, b} \leq F_{\max } & \text { valstybès, savivaldybès finansinių galimybiu apribojimas. } \mathrm{F}_{\max } \text { - } \\
& \text { maksimalios biudžetinès ir nebiudžetinès investicijos susisiekimo } \\
& \text { infrastruktūrai, transporto priemonèms birkti, susisiekimo sistemos } \\
& \text { eksploatacinès išlaidos, dotacijos ir susisiekimo lengvatos grupès } \\
& \text { gyventojams. }
\end{array}
$$

\section{Susisiekimo sistemos sprendinių paieška}

Tikslo funkcijų ir apribojimų sistemos matematinis sprendimas teoriškai būtų didelè pažanga planuojant susisiekimą. Ivertinant susisiekimo sistemos sudėtingumą, jos ypatybes, socialinių ir aplinkosauginių reikalavimų bei rinkos principų persipynimą, praktiškai įmanoma tik esamos susisiekimo sistemos tobulinimas, jos plétojimo varianty sudarymas, įvertinimas ir atrinkimas tikslo funkcijų ir apribojimų rémuose (5 pav.). 


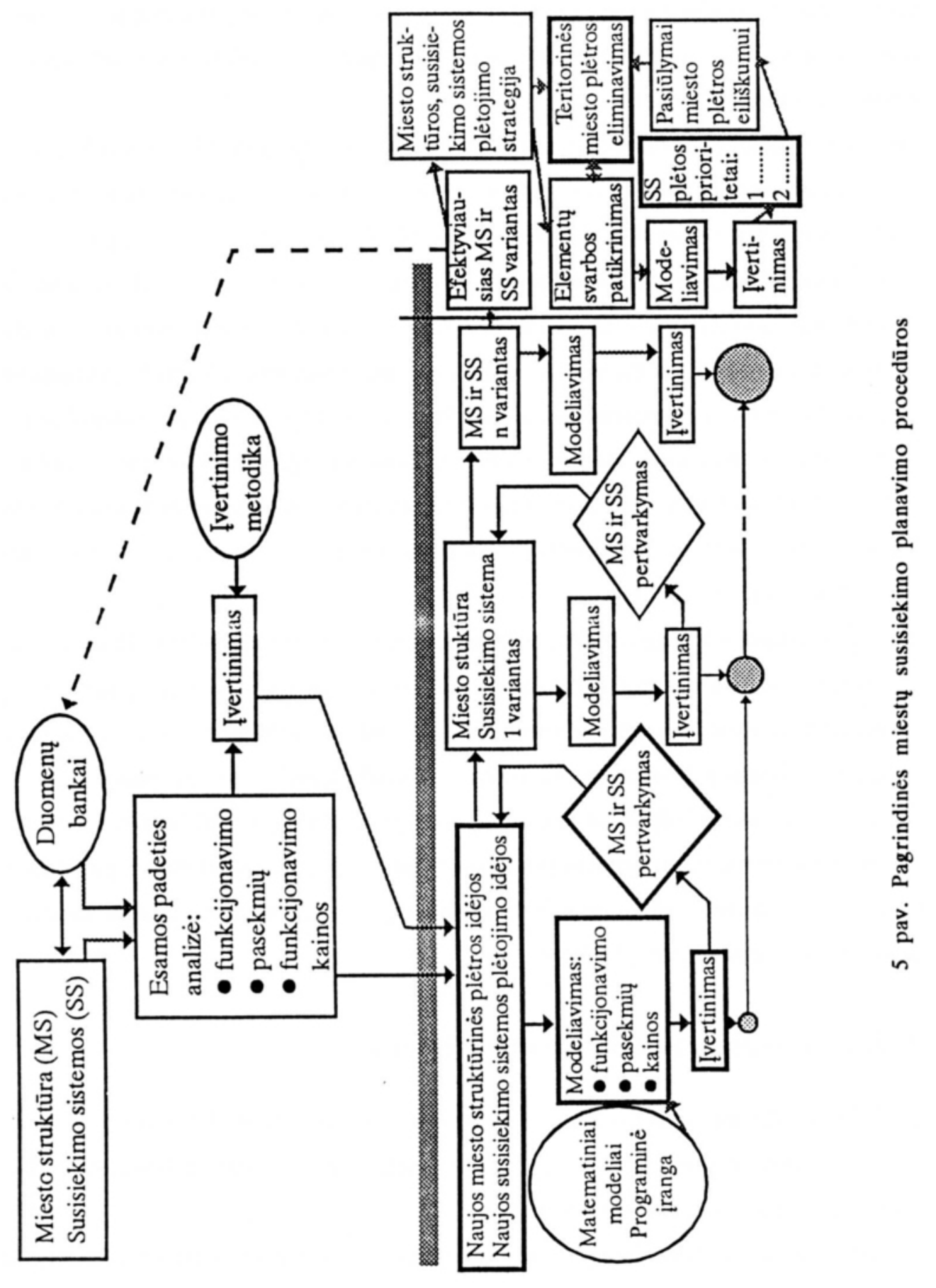


Susisiekimo sistemos sprendiniu variantų sudarymas, ju ịvertinimas ir vieno vadinamojo "geriausiojo" atrinkimas planavimo praktikoje visada egzistavo, nors tai galima pavadinti variantinio planavimo imitacija.

Variantinis miesto susisiekimo planavimas igauna tikrają prasmę tik naudojant matematinị funkcionavimo, pasekmių ir kainos modeliavimą bei pasitelkiant visą arsenalą priemonių, galinčiu pakeisti viena ar kita reikalinga linkme susisiekimo poreiki ir galimybes, susisiekimo sistemos funkcionavimą, pasekmes ir kainą.

Susisiekimo sistemos sprendinių paieška konkrečiam miestui gali vykti tokiais būdais:

1. Jeigu susisiekimo planavimas yra susijęs su miesto bendrojo plano sudarymu, tai susisiekimo ir miesto teritorinés bei funkcinès struktūros formavimas yra integruoto planavimo objektas. Pradinejje planavimo stadijoje visiškai nesvarbu, ar susisiekimo sistemos idejja padiktuos miesto plètros teritorinès ir funkcinès struktūros pradinị variantą, ar atvirkščiai. Modeliuojant susisiekimo poreikị, funkcionavimą, pasekmes ir kainą ir ivvertinus variantus, gali būti gautas integruotas sprendinys. Šiuo atveju büty gauti tokie rezultatai: integruota miesto ir jo susisiekimo sistemos pletros ilgalaike strategija ir susisiekimo politika (t.y., tai, kas tinka konkrečiai iš bendrojo priemonių arsenalo) bei konkretūs susisiekimo techninès infrastruktūros sprendiniai (gatvių tinklas ir jo parametrai, sankryžos, eismo režimas ir t.t.), konkuruojančios alternatyvos.

2. Jeigu susisiekimo planavimas reikalingas palyginti trumpam plètros laikotarpiui, miesto teritorinè ir funkcinè struktūra tampa konkrečia ir nekeistina aplinka. Tokiu atveju gali būti patikrintos visos hipotezès ir variantai, susiję tik su susisiekimo sistemos funkcionavimo sqlygų ir kainos pakeitimu (eismo režimu, mokesčiais, rinkliavomis ir pan.).

Šie du būdai duoda sąlygiškai baigtinius rezultatus. Tačiau nepriklausomai nuo planavimo rezultatų, gali atsirasti nenumatytų sąlygu ar ypatingų atvejų. Todèl atsiranda nepaprastai svarbi veiklos sfera - operatyvus planavimas ir tam reikalingas nuolatinis vykdomosios valdžios tarnybų kompiuterinès sistemos eksploatavimas.

\section{Plètojimo strategijos ir palankiausių investicijų paieška}

Susisiekimo planavimo tikslas nèra vien "geriausio" sprendinio ar alternatyvių, konkuruojančiu sprendinių paieška. A priori galima teigti, kad sprendinio realizavimo efektyvumas priklauso nuo plètojimo strategijos arba veiksmų eiliškumo.

Seniau buvo sudaromos pirmojo etapo (pirmajam planuojamojo periodo penkmexiui) darbų sąrašas, kai kada nurodant darbų eiliškumą. Tai formalus dalykas, nes esmé slypi ne čia. Plètojimo strategijos dalies uždavinys - atrinkti iš bendrojo susisiekimo sistemos sprendinio tuos elementus, kuriuos realizavus tam tikra tvarka, būtų gautas didžiausias efektas. Šį uždavinị, įvertinant ribotas finansines galimybes galima formuluoti kiek kitaip - atrinkti mažiausiai investiciju reikalaujanđius 
dalykus, kurie greičiausiai duotų didžiausią efektą. Praktiškai tai būtu palankiausių investicijų paieška. Todèl iškyla metodikos klausimas - kaip, kokiais kriterijais remiantis, nustatytinas efektas.

Plètojimo strategijos ar palankiausių investicijų kriterijus gali būti apibendrintas funkcionavimo, pasekmių ir kainos rodiklis, skaičiuojamas pagal tą pačią metodiką kaip ir ivertinant susisiekimo planavimo sprendinius. T.y., plètros strategija ir palankiausiu investiciju objektai gali būti surasti tuo pačiu susisiekimo sistemos funkcionavimo, pasekmių ir kainos modeliavimu esamos susisiekimo sistemos arba atrinkto "geriausio" ar alternatyviu planuojamy variantų rèmuose.

Susisiekimo sistemos plètojimo strategijos nustatymas yra susijęs su neapibrèžtumu. Vienas iš ju - miesto teritorinès plètros neapibrěžtumas:t.y.teritorijų užstatymo eiliškumas ir tempai. Jam esant ilgalaikè susisiekimo plètros strategija, ir palankiausių investicijų atranka yra problematiška. Vienintelè praktinè išeitis - savivaldybių tarnybų operatyvaus planavimo darbai.

\section{Finansinis aprūpinimas}

Tai būtų baigiamoji susisiekimo planavimo dalis, kurios paskirtis - nustatyti, kokiu mastu planavimo sprendiniai yra pagristi finansiniu požiūriu. Dabartinę situaciją galima apibūdinti kaip krizę. Léšų nepakanka net elementariai gatvių priežiūrai, viešojo keleivių transporto finansinis aprūpinimas garantuoja jo funkcionavimą tik su vis mažjančia kokybe, transporto priemonių parkas sensta, eismo valdymo ir reguliavimo įrangos kokybè atitinka trisdešimties mety senumo poreikius.

Atrodytų, kad savivaldybèms disponuojant nepaprastai mažais finansiniais resursais, ši procedūra nereikalinga. Tačiau finansinio aprūpinimo dalies uždavinys ne vien konstatuoti, užteks ar trūks lěšų, kurias pajègtu skirti miesto savivaldybé susisiekimo sistemos plètros reikmèms. Tiesa, tokia praktika anksčiau buvo įprasta ir, suprantama, nes nebuvo jokios finansavimo šaltinių, kainų ir kitų dalykų įvairovès, o, antra vertus, tai buvo ne susisiekimo planavimo specialistu kompetencija. Dabar taip pat neaiškus šios procedūros vykdytojas. Tikètina, kad pasiūlymo teisę susisiekimo planuotojai turès. Jie yra tuo suinteresuoti, nes iki šiol planavimo sprendinių "realumui" nustatyti taikomas principas: jeigu užtenka savivaldybès turimu lešų - "realūs", neužtenka - "nerealūs" sprendiniai. Todèl dažna situacija, kada net maksimalu efektą garantuojantis sprendinys, nežiūrint minimalių jo realizavimo išlaidų, pripažįstamas nerealiu, o turimos lèšs skiriamos smulkiems ir neaktualiems darbams.

Finansinio aprūpinimo dalies uždavinių visumą galima apibūdinti kaip tradicinių ir alternatyvių finansavimo šaltinių ir būdų paiešką bendrame susisiekimo planavimo kontekste:

tiesioginių ịplaukų už susisiekimo paslaugas, naudojimąsi technine infrastruktūra reglamentavimą (keleivių pervežimo tarifų, kitų paslaugų kainų pagrindimą), 
iplaukų iš valstybès nustatytų kelių ir kitų mokesčių, tenkančiu savivaldybei prognozé, dotacijų skyrimo ir panaudojimo principų nustatymas,

mokesčių, rinkliavų dydžių už parkavimą, įvažiavimą ị riboto eismo teritorijas pagrindimas ir efekto nustatymas, gautų pajamu panaudojimo principų nustatymas,

sąlygų, skatinančių ịplaukas susisiekimo sistemai finansuoti iš privačių struktūrų, transporto infrastruktūros, viešojo transporto privatizavimo sąlygos, galimybès ir efektas.

\section{Literatūra}

1. П.В.Юшкявичюс. Транспортное обслуживание сельского населения агропромышленного комплекса. Москва: Транспорт, 1989. 164 с.

2. M.-H.Poing Londres en retard d'un metro sur Paris. Vie rail, 1992, p. 21-22.

3. R.S.Timberlake. Traffic modeling techniques for the developing word: case studies // Transportation Research Record, 1988, No 1167, p. 28-34.

\section{PROCEDURES OF CITY TRANSPORT SYSTEMS' PLANNING}

\section{P.Juškevičius}

S u m m a r y

The article starts with looking into a treatment of the objects of city transport systems planning: administrative (determined) and systematic approach, that are of importance for the principles of planning and its quality.

The major shortages of the traditional planning are the following: its determination, narrow functional attitude towards the processes of transportation, lack of evaluation of the interrelations between a city structure and its transport system.

There are several obstacles to shift to the planning of higher quality, namely poorly arranged information supply, shortage of mathematical models for transport processes and relevant soft ware. Considering the gained experience of transport system planning and professional knowledge on transport systems, a new methodology of planning is presented. A major stress here is put on the complex of transport system functioning, the consequences and the price. 